УДК: 378.147:81'243

\title{
PRINCIPLES OF LEXICAL MINIMUM SELECTION FOR TEACHING GENERAL TECHNICAL ENGLISH TO ENGINEERING STUDENTS
}

\author{
O. L. Yaroshenko \\ Kyiv, National Technical University of Ukraine \\ "Kyiv Polytechnic Institute" \\ olga.yaroshenko@gmail.com
}

\begin{abstract}
The article covers problems related to selecting lexical material for teaching engineers-to-be and surveys the history of the problem. It contains the definition of the "lexical minimum" as a term, and analyses principles of selecting the lexical minimum based both on topics covered by English for Technical Purposes program and requirements for the B2+ level which is the target level of studying English during the first two years on technical faculties. The article explains the importance of selecting the lexical minimum as it makes up the base for exercises used to form lexical competence in reading, speaking, listening, writing and translating. The absence of the lexical minimum makes it much more difficult for a teacher to control and evaluate the formation of the foreign language competence. Taking into account that selection of lexical minimum must be carried out with consideration of many factors (such as program requirements, learning environment and language skills) and certain principles and procedures, it is necessary to draw up an algorithm of actions to select lexical units. The article has four parts: an introduction explaining the topicality, aims and objectives of the article, two parts with the main research material and conclusions.
\end{abstract}

Key words: lexical minimum, lexical competence, lexical skills, active vocabulary, passive vocabulary.

Introduction. Lexical minimum selection, being one of the components of the overall process of course content selection, is one of the compulsory steps in program design (along with defining real needs of community and personality, formulating the aims of a course, creating a structural model of a course, developing the content and forms of control). Along with it, the lexical competence is an integral part of foreign language communicative competence because lexical skills provide functioning of such types of language skills as writing, speaking, reading, listening and translation. Formation of language skills in General Technical English, which is studied during the first stage of technical university, implies the existence of lexical minimum which would be a model of General Technical English and would keep its major function communicative. Education in higher technical schools places its own requirements like a definite number of class hours and different specializations which in its turn necessitate selection of language material to correspond the purposes and content of studying general technical English during the first stage of technical universities.

It explains the relevance of this article's topic: the lexical minimum makes up the base for exercises used to form lexical skills in reading, speaking, listening, writing and translating. Its absence makes it much more difficult for a teacher to fulfill an adequate control and evaluation of the level of formation of the foreign language competence. As soon as selection of lexical material must be done in accordance with a lot of factors (program requirements, terms of study, language 
level) and definite principles and procedures, there is a need to make an algorithm of possible actions to select lexical units.

The task of the article is to analyze different approaches to selecting the lexical minimum and to formulate main principles of selecting the lexical minimum for teaching General Technical English to engineering students based on both program requirements and CEFR.

Lexical minimum: definition and the history of the problem. Lexical minimum is a vocabulary which comprises frequently used lexical units that represent the greatest value in certain communication conditions. Lexical minimum is a term used mainly in post soviet methodology and corresponds to the term "minimum vocabulary" in English. In our article we prefer to use the former. The lexical minimum consists of active and passive vocabularies. Active lexical minimum is the lexical material which students have to use for expressing their thoughts in speaking and writing and understand other people's thoughts while listening and reading. Passive lexical minimum is the vocabulary that students have to understand when perceiving others' thoughts while listening and reading [1, p. 93].

The first educational minimum vocabularies were compiled at the beginning of the twentieth century (Eldridge, Thorndike, Morgan, Frances, Eaton et al.). The basic principle of words selection was frequency. Frequency dictionaries are the lists of words arranged by decreasing the frequency of their use in speech or text.

The first frequency dictionaries were compiled based on statistical calculations of specially selected words in different literature. Yet the literature selection was very limited and often subjective. Words from texts were written down on cards, and the most frequent words were located either alphabetically or by frequency basis. Having done a tremendous job, in 1921 F. L. Thorndike in his Teacher's Word Book dictionary collected 10 thousand of the most commonly used English words, which had been selected on the basis of analysis of various texts containing 4 million word uses in total.

In 1930 a famous British writer and linguist Charles Kay Ogden published his Dictionary of Basic English comprising 850 words which, according to him, were quite enough for elementary communication. The dictionary was compiled based not on the frequency principle, but on logical and philosophical principles. First, Ogden tried to define the most essential ideas and concepts, and then he selected the simplest basic words for these concepts. That is why the dictionary comprised 200 names of particular objects, 400 common names, 150 words to describe properties and 100 words-operators (as Ogden called them). Among those operators there were 18 verbs and other parts of speech (for example: can, do, across, after, to, the, all, if, not, very and other words mainly pronouns, articles, adverbs, prepositions and others). Ogden's next step was Dictionary in Basic English published in London in 1940. The dictionary had 20 thousand words which were explained with the help of only those 850 words from Basic English system listed as a supplement to the dictionary.

In 1934 Harold E. Palmer with a co-author Albert S. Hornby published Standard English Vocabulary which became the base of the whole range of Hornby series dictionaries and handbooks.

In 1935 in Toronto University Michel West published Definition Vocabulary with 1,500 words. That very year in London The New Method Dictionary was 
published with 18 thousand words and 6 thousand idioms interpreted with the help of West's lexical minimum of 1,500 words. In 1953 Longman Publishing House published A General Service List of English Words by Michel West. The target audience was English language learners and ESL teachers. The General Service List was not a list based solely on frequency, but included groups of words on a semantic basis.

In 1934-1935 Carnegie Fund organized an international conference of linguists whose task was to synchronize 12 word lists existing at the time to provide more rational and systematic base for learning English vocabulary. The conference was followed by publishing the Interim Report on Vocabulary Selection comprising the 2,000 most frequently used words found in English text. This task was accomplished by compiling a running text of five million words taken from a broad selection of reading material; words were then tabulated on the basis of frequency.

In modern methodology of teaching ESL there are a number of approaches formed for selecting lexical material. Among them there are ones based on empirical principle, topics, thesaurus, lexicography, statistics, communicative approach and other. The next part of the article surveys some of these principles of lexical unit selection.

Selecting lexical material for teaching engineering students. Using principles and methods of compiling minimum vocabulary mentioned above, and based on Common European Framework of Reference for Languages and ESP program, we may try to draw an algorithm of lexical unit selection for teaching general technical English.

English for Specific Purposes 2005 program states that the aim of teaching ESP in technical universities is to form professionally oriented competence which is the sum of knowledge, abilities and skills implied by students mastering in engineering to use English to get and convey information in the field of their future profession and scientific researches [7, p.10].

According to ESP program students' entry level must be B1+ - a Strong Threshold. The target level for bachelors is B2+- a Strong Vantage. For moving from B1+ up to B2+ students are given 200 hours of class hours. During the first and second years of study engineers-to-be must reach B2. At this stage, engineering students study general technical foreign language.

According to ESP program and Educational Qualification Characteristics we can clearly define language skills which students have to master in writing, speaking, listening, reading and translation. This fairly extensive list of skills that students need to develop sets a certain practical goals of forming language competence. It provides clear guidance for selection of a learning content (topics and interaction situations, language material, communicative functions, examples of oral speech texts, presentations and so on).

Based on the fact that the B2+ is the target level, we'd like to remind the requirements for this level. So, for a bachelor's degree, along with all the other professional skills, a student must be able to communicate effectively in English in a professional environment to:

- discuss academic and profession related issues in order to reach understanding with a partner; 
- prepare public speeches on a number of professional issues using appropriate means of verbal communication and adequate forms of discussion and debate;

- find new information in English from any type of source (text, graphical, video, audio) using appropriate search methods and terminology;

- analyze English sources of information to obtain data that are necessary to perform professional tasks and make professional decisions;

- write profession related texts and documents in English;

- write business letters demonstrating intercultural understanding and prior knowledge in a specific professional context;

- translate profession related texts from English into native language using bilingual terminology dictionaries and certain software for translation [5, p. 28].

Content selection for the Typical ESP program is based on analysis of national and international educational standards, professional requirements and student needs to provide conditions for students for achieving B2+ level required by bachelor's degree. This level provides academic and professional mobility of students, allowing them to function competently in professional and academic contexts and provides them with the basis for learning throughout life. ESP program content is aimed at forming professional communicative competence, which is regarded as language behavior specific to academic and professional environment.

While selecting lexical elements for teaching ESP it is also helpful to employ Vantage (2001) - a publication by the Council of Europe. Concerning characteristics of B2 lexical thematic content frame J. A. van Ek and J. L. M. Trim in their Introduction to Vantage level claimed that Vantage level goes beyond Threshold level particularly in the following respects:

- the refinement of functional and general notional categories, with a consequent growth in the available inventory of exponents;

- a considerable enlargement of concrete vocabulary expressing specific notions in thematic areas;

- above Threshold level learners are expected to be more autonomous, able to take increasing responsibility for their learning and able to make more effective use of reference books and other information sources in order to develop a vocabulary appropriate to their own needs and interests;

- recognition and limited control of important register varieties; learners are expected to have more experience of the situations which call for more formal or more colloquial usage and judge when they may appropriately follow suit. [6, p. 3].

J. A. van Ek and J. L. M. Trim offer classification of communicative functions, general and specific notions and forms of their expressing. Vantage (2001) by the Council of Europe can be recommended as a valuable resource for curriculum planners, course designers and materials producers. A useful analysis of this publication was done by V.V. Safonova. Concerning lexical competence, she concludes that mastering vocabulary involves the use of compensatory strategies. The interaction between universal notions, which can be expressed in speech, and language tools of their expression in English can be revealed within the eight 
common notion categories, each with some notion groups, from which one may select certain lexical units and grammar structures [2, p. 136].

O. B. Tarnopolskyi determines the size of passive and active vocabulary for teaching students of engineering faculties. For the first stage of learning, the passive lexical minimum accounts for approximately 1,500-1,600 units which belong to the layer of generally used and general scientific vocabulary. The size of the active minimum is $800-900$ units, which is enough for speaking and writing within general technical themes and certain circle of communication tasks. [4, p. 37-38].

According to the general algorithm of course content selection offered by Y. N. Solovova, formation of lexical frame must be preceded by selection of topics and situations of communication. [3, p.75]. The analysis and comparison of up-to-date textbooks used for teaching General Technical English (Oxford English for Careers: Technology (2007), Engineering Workshop, Cambridge English for Engineering (2008)), allow to make a list of such topics and situations as they are quite common for this specialization.

\begin{tabular}{|c|c|}
\hline Topics & Possible topics of communication \\
\hline Technology in Use & $\begin{array}{ll}\text { - } & \text { Describing technical functions and applications } \\
\text { - } & \text { Explaining how technology works } \\
\text { - } & \text { Emphasizing technical advantages } \\
\text { - } & \text { Simplifying and illustrating technical explanations }\end{array}$ \\
\hline Materials Technology & $\begin{array}{ll}\text { - } & \text { Describing specific materials } \\
\text { - } & \text { Categorizing materials } \\
\text { - } & \text { Specifying and describing properties } \\
\text { - } & \text { Discussing quality issues }\end{array}$ \\
\hline $\begin{array}{l}\text { Components and } \\
\text { assemblies }\end{array}$ & 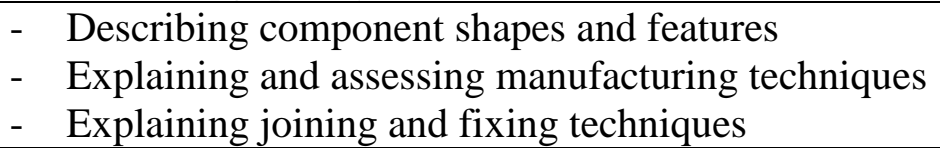 \\
\hline Engineering design & $\begin{array}{ll}\text { - } & \text { Working with drawings } \\
\text { - } & \text { Describing design phases and procedures } \\
\text { - } & \text { Resolving design process }\end{array}$ \\
\hline Technical development & $\begin{array}{ll}\text { - } & \text { Discussing technical requirements } \\
\text { - } & \text { Suggesting ideas and solutions } \\
\text { - } & \text { Assessing feasibility } \\
\text { - } & \text { Describing improvements and redesigns } \\
\end{array}$ \\
\hline $\begin{array}{l}\text { Procedures and } \\
\text { precautions }\end{array}$ & $\begin{array}{ll}\text { - } & \text { Describing health and safety precautions } \\
\text { - } & \text { Discussing regulations and standards } \\
\text { - } & \text { Working with written instructions and notices }\end{array}$ \\
\hline Monitoring and control & $\begin{array}{ll} & \text { Describing automated systems } \\
\text { - } & \text { Referring to measurable parameters } \\
\text { - } & \text { Discussing readings and trends } \\
\end{array}$ \\
\hline Theory and Practice & $\begin{array}{ll}- & \text { Explaining tests and experiments } \\
- & \text { Exchanging views on predictions and theories }\end{array}$ \\
\hline Careers in technology & $\begin{array}{ll}- & \text { Writing CV } \\
- & \text { Doing a job interview } \\
\end{array}$ \\
\hline Technical problems & $\begin{array}{ll} & \text { Describing types of technical problems } \\
\text { - } & \text { Assessing and interpreting faults } \\
\text { - } & \text { Describing the causes of faults } \\
\text { - } & \text { Discussing repairs and maintenance } \\
\end{array}$ \\
\hline
\end{tabular}


Conclusions. Having analyzed the works by different researchers concerning approaches to selecting lexical material, we can conclude that selection process must be carried out on the base of the ESP curriculum and B2 descriptors of CEFR. Selection of lexical minimum must be preceded by defining and selecting appropriate topics and situations for communication. Vocabulary selection must be carried out based on a systemic approach. All these results can be used for the further researches on forming lexical competence of engineering students.

\section{ЛIТЕРАТУРА}

1. Методика викладання іноземних мов у середніх навчальних закладах: [Підручник] / Кол. Авторів під керівн. С. Ю. Ніколаєвої. - К.: Ленвіт, 2002. -328 c.

2. Сафонова В. В. Коммуникативная компетенция: современные подходы к многоуровневому описанию в методических целях / Серия: О чем спорят в языковой педагогике. - М.: Еврошкола, 2004. - 236с.

3. Соловова Е. Н. Методика обучения иностранным язикам: продвинутый курс: [пособие для студентов пед. вузов и учителей] / Е. Н. Соловова. - М.: Астрель, 2008. - 272 с.

4. Тарнопольський О. Б. Методика навчання англійської мови на II курсі технічного вузу: [Підручник] / О. Б. Тарнопольський. - К.: Вища школа, 1993. - $167 \mathrm{c}$.

5. Council of Europe. Common European Framework of reference for languages: learning, teaching, assessment [Електронний ресурс] / Council of Europe. - Режим доступу до ресурсу: http://www.coe.int/t/dg4/ linguistic/cadre1_en.asp.

6. Ek. J. A. van Vantage / J. A. van Ek, J. L. M. Trim. - Cambridge: Cambridge Univ. Press, 2001. - 192 p.

7. English for Specific Purposes (ESP) National Curriculum for Universities / [Г.С. Бакаєва, О.А. Борисенко, I.I. Зуєнок та ін.]. - К.: Lenvit, 2005. $-108 \mathrm{c}$.

\section{REFERENCES}

1. Nikolayeva, S. Y. (Ed.) (2002) Methods of teaching foreign languages in schools. Kyiv: Lenvit [in Ukrainian].

2. Safonova, V. V. (2004). Communicative competence: modern approaches to multilevel description in methodical purposes. Moscow: Evroshkola [in Russian].

3. Solovova, E. N. (2008). Methods of teaching foreign languages: advanced course.Moscow: Astrel [in Russian].

4. Tarnopolskyi, O. B. (1993). Methods of teaching English on the second course of technical university. Kyiv: Vyshcha shkola [in Ukrainian].

5. Council of Europe. Common European Framework of reference for languages: learning, teaching, assessment. Available from http://www.coe.int/t/dg4/linguistic/cadre1_en.asp

6. Ek, J. A. van \& Trim, J. L. M. (2001). Vantage. Cambridge: Cambridge Univ. Press.

7. Bakayeva, G.Y., Borysenko, O. A., Zuyenok, I. I. English for Specific Purposes (ESP) National Curriculum for Universities. Kyiv: Lenvit [in Ukrainian]. 
О. Л. Ярошенко. Принципи відбору лексичного мінімуму для навчання загальнотехнічної англійської мови студентів інженерних спеціальностей.

Розглядаються питання, пов'язані 3 відбором лексичного матеріалу для навчання студентів інженерних спеціальностей. Дається визначення лексичного мінімуму як терміна, аналізуються принципи відбору лексичного мінімуму, грунтуючись на навчальній програмі English for Specific Purposes i дескрипторах рівня В2+ «Загальноєвропейських рекомендацій 3 мовної освіти». У статті пояснюється важливість відбору лексичного мінімуму, так як він $є$ основою для складання вправ, які використовуються для формування лексичної компетенції в усіх видах мовленнєвої діяльності. Відсутність лексичного мінімуму значно ускладнює роботу викладача з формування цієї компетенції, а також унеможливлює належний контроль сформованості іншомовної компетенції.

Ключові слова: лексичний мінімум, лексична компетенція, лексичні навички, активний мінімум, пасивний мінімум.

О. Л. Ярошенко. Принципы отбора лексического минимума для обучения общетехническому английскому языку студентов инженерных специальностей.

Рассматриваются вопросы, связанные с отбором лексического материала для обучения студентов инженерных специальностей. Дается определение лексического минимума как термина, анализируются принципы отбора лексического минимума, основываясь на учебной программе English for Specific Purposes и дескрипторах уровня B2+ «Общеевропейских компетенций владения иностранным языком». В статье объясняется важность отбора лексического минимума, так как он составляет основу для составления упражнений, которые используются для формирования лексической компетенции во всех видах речевой деятельности. Отсутствие лексического минимума значительно затрудняет работу преподавателя по формированию этой компетенции, а также делает невозможным адекватный контроль.

Ключевые слова: лексический минимум, лексическая компетенция, лексические навыки, активный минимум, пассивный минимум. 